\title{
Şenol Turan'ın Alaturka Münzevi Romanında Anlatıcı ve Bakış Açısı Üzerine Bir Değerlendirme
}

\author{
Fatma Şükran Elgeren ${ }^{\mathrm{ab}}$
}

Özet

Alaturka Münzevi, asıl mesleği kaymakamlık olan; fakat yazdığı hikâye ve romanlarla, ileride edebiyatımızın son dönem yazarları arasında isminden söz ettireceğe benzeyen Şenol Turan tarafından kaleme alınmış bir romandır. 2015 yılında Deli Adamlar Ülkesi adlı hikâye türündeki eseriyle edebiyata merhaba diyen Turan'ın ikinci kitabı ve ilk romanı olan Alaturka Münzevi, yazarların anlatımdaki kısıtlılığı sebebiyle fazla itibar etmedikleri "ben anlatıcı ve tekil bakış açısı" ile yazılmış olması bakımından dikkate değer bir çalışmadır. Müşahit anlatıcıya göre daha dar bir bakış açısına sahip olan ben anlatıcı, genellikle otobiyografik eserler ya da günlük türündeki metinlerde karşımıza çıkar. Alaturka Münzevi'de sözü edilen bu özellikler bulunmamasına rağmen ben anlatıcının ve tekil bakış açısının kullanımı ile söz konusu anlatıcının sinırlılıklarını gidermek için yapılan bazı uygulamalar, esere incelenmeye değer bir nitelik kazandırmıştır. Bu sebeple elinizdeki çalışmada söz konusu eser, anlatıcı ve bakış açısı unsurları üzerinden değerlendirilecektir.
Anahtar Kelimeler

Alaturka Münzevi

Şenol Turan

Anlatic1

Bakış Açısı

Makale Hakkında

Geliş Tarihi: 16.10 .2020

Kabul Tarihi: 10.05.2021

Doi: 10.18026/cbayarsos. 811460

\section{An Evaluation on the Narrator and His Perspective in Şenol Turan's Novel Alaturka Münzevi}

\begin{abstract}
Alaturka Münzevi, whose main profession is the district governor; However, it is a novel written by Şenol Turan, who seems to be mentioned among the last period writers of our literature with the stories and novels he wrote. Turan's second book and his first novel, Alaturka Münzevi, who welcomed literature with his story-style work titled Deli Adamlar Ülkesi in 2015, is a remarkable work in that it was written with a "I narrator and singular perspective", which the authors do not appreciate much due to their limitations in expression. The self-narrator, who has a narrower perspective than the observant narrator, usually appears in autobiographical works or diary-type texts. Despite the absence of these features mentioned in Alaturka Münzevi, some applications made to eliminate the limitations of the narrator in question through the use of the self-narrator and singular point of view have made the work worth studying.
\end{abstract}

Keywords

Alaturka Münzevi

Şenol Turan

Narrator

Point of View

\section{About Article}

Received: 16.10 .2020

Accepted: 10.05.2021

Doi: 10.18026/cbayarsos. 811460

\footnotetext{
a İletişim Yazarı: fatmasukran_aslan@hotmail.com

b Dr. Öğr. Üyesi, Manisa Celal Bayar Üniversitesi Eğitim Fakültesi /Demirci / ORCID: 0000-0003-1822-2982
} 


\section{Giriş}

Anlatma esasına bağlı türlerin, tabiatı itibariyle iki temel özelliği taşıması beklenir. Bunlardan ilki anlatılacak bir hikâyenin varlığı, diğeri ise bu hikâyeyi okuyucuya iletecek olan bir anlatıcıdır. Destan, masal ve efsane gibi gerçek dışılığa bağlı türlerden günümüz anlatılarına dek hayli değişim gösteren hikâye ve anlatıcı kavramları, bazı yazarlara göre her şeye rağmen anlatıların olmazsa olmaz unsurları olarak görülürken, özellikle postmodern dönemin tesirinde kalan bir diğer kesime göre ise anlatıdaki önemi gittikçe azalan ve anlatılardan silinmeye çalışılan kavramlardır.

Postmodern algı her ne kadar belirsizlik üzerine inşa edilen metinler ortaya çıkarmış olsa da, roman sanatının tabii karakteri az ya da çok, bir şekilde varlığı hissedilen bir hikâye ile onu anlatacak bir varlığın zorunluluğunu ortadan kaldıramamıştır. Zira anlatıcı, romancının meramını okura ulaştıracak olan, romancı ile okur arasında bir kişidir. Romanda olan biten bütün hadiseleri, roman kişilerini, onların düşünce, davranış, his ve hayallerini, mekânı, zamanı, başka bir deyişle romana ait her şeyi okura aktaran kişi, anlatıcıdır. Anlatıcı bütün bunları yaparken öznel ya da nesnel bir tavır takınabilir. Okura aktardıklarını yorumlayarak eleştiride bulunabilir. Nesnel davranmayı tercih ederek hadiselere yalnızca ayna tutabilir yahut araya girerek okura varlığını hissettirebilir. Anlatıcı, yazarın tasarrufuna göre romanda geçen hikâyenin kişilerinden biri ya da tamamen olayların dışında kalan biri olabilir. Fakat ne şekilde olursa olsun roman yazarı ile anlatıcı aynı kişi değildir. Yazar içinde yaşadığımız dünyanın insanıken; anlatıcı kurgusal dünyaya aittir. (Çetin, 2015, s.104) Kurgusal dünyaya ait olan bu varlık, değişen hayat şartlarının da tesiriyle, konumu ve önemi bakımından bir başkalaşım geçirmiştir.

Tarihi serüveni içinde anlatıcı, toplumsal ve kültürel yapıdaki değişimlere paralel olarak farklı konum ve niteliklerde karşımıza çıkar. Esas itibariyle anlatıcının konumunu sanatçının tercih ve eğilimlerinin belirlediğini söylemek yanlış olmaz. Zira dünün her şeyi bilen ilahi karakterli anlatıcısı, bugün yerini beşeri bir portreye bırakmıştır. Anlatıcının konumundaki bu değişiklikte edebi ve estetik beklentiler kadar, toplumsal ve kültürel beklentilerin de tesiri olmuştur. (Tekin, 2016, s. 23) Sözlü geleneğin gür sesi olan destan türünde anlatıcı, neredeyse hikâyesi kadar ön plana çıkarken kendini gizleme gereği duymamıştır. Çünkü ortada duyurulması gereken bir şey vardır ve amaç bunu en tesirli şekilde mümkün olduğunca fazla kişiye duyurabilmektir. Ancak destandan romana gelinceye kadar değişen toplumsal ve kültürel şartlar, romanı farklı bir tür mesabesinde ortaya çıkardığı gibi, bu türün miras olarak devraldığı anlatıcı unsurunu da değişikliğe uğratmıştır.

Batı' da 19. yüzyılın sonlarına kadar romancı kendisini ahlakçı ve biraz da filozof saydığından, hikâyesini anlatırken araya girerek kişileri hakkında düşüncelerini açıklamayı, hatta onların davranışlarını ahlaki açıdan değerlendirmeyi bir yazarlık vazifesi olarak görmekteydi. Bu da anlatıcının fazlaca göze batması ve kişilik kazanması demekti. (Moran, 1983, s. 49) Bu bağlamda ele alındığında anlatıcı, her ne kadar itibari bir varlık olsa da, yazarın dilini kullanarak içinde bulunduğu kurmaca dünyanın şahıs kadrosunu ve hayat tezahürlerini dikkatlere sunar ya da nakleder. Bu şekilde hâkim bakış açısından hareketle yazılmış eserlerdeki anlatıcı, Aktaş'a göre yazar-anlatıcı olarak nitelenebilir. Yazar-anlatıcı nakledilen itibari âlemle ilgili her şeyi bilen ve gören bir mevkidedir. Bu bakımdan o, itibari âlem içinde sınırsız bir güce sahiptir. (Aktaş, 2003, s. 89) Bu durum 19.yüzyıla gelene kadar roman sanatı ve romancı açısından sıkıntı yaratmaz; fakat realistlerin romana yükledikleri yeni anlam, anlatıcının söz konusu konumunu sarsmaya başlar. Zira realistlere göre roman, bireyi ve 
toplumu anlatmada güçlü bir araçtır. Bu bakımdan romancı ile roman arasındaki bağın kopması, romanda olması gereken objektif tutumun varlığı için elzemdir. (Tekin, 2016, s. 2829) Yazar-anlatıcının ağırlığını ortadan kaldırmaya başlayan bu süreç, farklı edebi akımların da tesiriyle günümüze kadar uzanır. Her ne kadar anlatıcı kavramı postmodernizmin tesiriyle roman düzleminden tamamen silinmeye çalışılsa da, romancı ile arasındaki organik bağ, anlatıcının varlığını zorunlu kılmaya devam etmektedir.

Günümüzde roman sahasında temel olarak I.teklik kişi (ben), III. teklik kişi (o) ve II. çokluk kişi (siz) olmak üzere üç tip anlatıcıdan söz edilebilir. Bunların dışında birden çok anlatıcıya yer verilmesini sağlayan "çoğul anlatıcı" da özellikle son dönem yazarların tercih ettiği bir diğer anlatıcı tipidir. Sözü edilen bu anlatıcı tipleri arasında en az kullanılanı II. çokluk kişi (siz) anlatıcıdır. Bu, marjinal bir anlatıcıdır ve romancıya olağanüstü sınırlamalar getirir.

Yazarlara tanıdığı geniş imkânlar sebebiyle en fazla rağbet gören anlatıcı tipi, "o" anlatıcıdır. Zira "o", romanda sesini duyduğumuz ilk kişi olmasına rağmen, mutlaka bir insan olması bile gerekmeyecek kadar özgürdür. “O”nun teşhis edilmiş, yani kişilik kazandırılmış herhangi bir varlık olması dahi mümkündür. Böyle bir kullanımda herhangi bir kahraman ya da kahraman süsü verilmiş herhangi bir varlık konuşabilme, görebilme ve düşünebilme kabiliyetleri ile donatılabilir. Bu bakımdan anlatıcı mutlak bir gücün sahibidir. III.teklik kişi ya da diğer bir deyişle müşahit anlatıcı, ilahi bakış açısı ile birlikte kullanıldığında sözü edilen mutlak güç, kendini gizleme gereği bile duymayabilir. İlahi bakış açısına sahip anlatıcı, sesi ve etkileme gücüyle her yerde hazır ve nazırdır. Görüp bilmediği hiçbir şey yoktur. Anlatının kişi, olay, zaman ve mekân gibi unsurları üzerinde sınırsız bir tasarruf hakkına sahiptir. (Tekin, 2016, s. 31-34)

İncelenecek olan eserde de tercih edilen I. teklik kişi, ben anlatıcı ise, yapısından kaynaklanan bazı eksiklikler sebebiyle müşahit anlatıcıya göre daha az denenen bir anlatıcı tipidir. Yazara bazı kısıtlamalar getirse de ben anlatıcı, romandaki lirik sıcaklığı sağlamak konusunda diğer anlatıcı tiplerine göre bir adım öndedir. Ben anlatıcı, müşahit anlatıcıda olduğu gibi anlatı dünyasının dişında ya da üstünde bulunma gücüne sahip değildir. Ben anlatıcı, hem anlatan hem de anlatılan figür konumunda bulunduğu için, okuyucu olaylara onun bakış açısının izin verdiği ölçüde tanık olur. Kişi ve nesneleri onun gözüyle tanımaya ve anlamaya çalışır. (Tekin, 2016, s. 47-48) Dolayısıyla ben anlatıcı, okuyucuya müşahit anlatıcıya göre daha dar bir bakış açısı getirebilir. Fakat anlatımın daha lirik bir karakter taşıması sebebiyle kahraman ve anlatıcı, hatta okur ve kahraman arasında özdeşleşmeyi sağlaması daha kolaydır. Ancak her halükarda bu anlatıcı tipinde anlatıcı ile anlatan arasındaki mesafeyi makul düzeyde tutmak hayli zordur. Anlatıcının her şeyi görüp bilecek donanıma sahip olması bile, anlatımın ideal seviyede gerçekleştiğini göstermez. Zira bu sefer de ortaya anlatıcının kendisini anlatamama meselesi çıkmaktadır. Bunun çözümü için yapılacak iş, ben anlatıcıya zarar vermeden bazı yan uygulamaları devreye sokmaktır.

Bu uygulamalardan ilki anlatıcının görme ve sezme gücünü artırarak onu daha donanımlı kılmaktır. Bu suretle anlatıcı kendi mizaç ve kültüründen birtakım izler bırakarak çevreyi ve eşyayı anlatabilir. Bir diğer uygulama, anlatıda gözlemci kahramana yer vermektir. Bu kahraman sayesinde, ben anlatıcının yükü hafifler. Gözlemci kahraman, doğrudan anlatıcı hakkında birtakım bilgiler verebilir ya da anlatıcının kendisini anlatmasına aracı olur. $\mathrm{Bu}$ uygulamada gözlemci kahramanın anlatıcıyı yakından tanıması ve onun hakkında geniş bir bilgiye sahip olması beklenir. Bunlardan başka üçüncü bir uygulama da, yazarın mektup ve anı türünden yararlanmasıdır. Bu suretle yazar, roman içinde zaman zaman çeşitli anı 
parçalarına yer vererek anlatıcının kültürel durumu, amaçları, arzu ve özlemleri hakkında okuyucuya çeşitli ipuçları gönderebilir. Benzer şekilde eserde mektuplara yer verilmesi de aynı amaca hizmet eder. Sözü edilen bu uygulamalarla ben anlatıcının önündeki engeller nispeten ortadan kaldırılmış olur. (Tekin, 2016, s. 50-52)

Romanda anlatıcı kadar önemli olan bir diğer kavram da bakış açısıdır. Bakış açısı, vaka zincirlerinin, mekân, zaman, şahıs kadrosu gibi unsurların kim tarafından görüldüğü, idrak edildiği ve kime nakledildiği sorularının cevabıdır. Anlatma esasına bağlı edebi eserlerde mühim bir yeri olan ve diğer unsurları çevresinde toplayan vaka zincirinin şekli, başlangıç ve bitiş noktası, büyük ölçüde bakış açısına bağlıdır. Eserde şahısların teşekkülü ve tanıtılması, mekânın tasviri gibi konularda da üzerinde durulacak unsurlardan biri bakış açısıdır. (Aktaş, 2003, s. 76-78) Bir romancı asıl hedefi olan anlatma olayını gerçekleştirmek için modern romanın gelişimine paralel olarak ortaya çıkan bakış açılarından birini tercih etmek zorundadır. Bu tercih, olayların kapsamı, anlatıda yer alan kişilerin işlevi, dil, üslup ve verilecek mesajla bağlantılı bir tercih olacağ için, bakış açısının seçimi sıradan bir iş değildir. Günümüzde roman sahasında tanrısal (ya da hâkim), gözlemci (ya da müşahit), tekil (ya da kahraman) ve çoğul bakış açısı olmak üzere dört tür bakış açısından söz edilebilir.

Tekin'in "destandan romana intikal etmiş" bir yöntem olarak nitelediği tanrısal bakış açısı, temel karakteri itibariyle her şeyi bilme esasına dayanan ve yazara en geniş imkânı sunan bakış açısıdır. Bu bakış açısının kullanıldığı eserlerde anlatıcı, kendisine tanınan özgürlükle her şeyi bilir, görür, sezer, geçmiş ve hatta gelecekten haber verir. $\mathrm{O}$, kelimenin tam anlamıyla her şeye hâkimdir.

Tanrısal bakış açısına sahip anlatıcının sınırsız gücüne karşılık daha kısıtlı imkânlara sahip olan gözlemci bakış açısı ise, bütün benliği ile kurmaca yapının içinde yer alır. Yazar onu bilinçli olarak anlatı sisteminin içine yerleştirir ve anlatının olay, zaman ve mekân gibi unsurlarını onun bakış açısından sunar. Bu noktada anlatmada objektifliğin sağlanabilmesi için, onun gözlemci yeteneğinin ön plana çıkarılması; hadiseler ve nesnelerin onun gözlemci yeteneğine ve kültür düzeyine göre aktarılması gerekir.

Bunlardan başka modern romanın ivme kazandığ1 vakitlerde ortaya çıkmış olan çoğul bakış açısı, tanrısal bakış açısından vazgeçemeyen romancıların diğer bakış açılarını birer birer devreye sokarak insanı farklı cephelerden anlatmak istemelerinin bir sonucudur.

Genellikle otobiyografik romanlarda kullanılan tekil bakış açısı ise, romanda anlatıcı ile anlatılanı aynı düzlemde birleştirir. Bu sebeple "kahraman anlatıcı" olarak da isimlendirilir. $\mathrm{Bu}$ tür romanlarda anlatının bütün malzemesi merkezi kişi konumundaki kahraman tarafından okura aktarılır. Bu durum, yazarın varlığını nispeten ortadan kaldırmaktadır. Tekil bakış açısı, genellikle ben anlatıcı ile kaleme alınmış romanlarda kullanılan bir bakış açısıdır. (Tekin, 2016, s. 57-64) Alaturka Münzevi, otobiyografik özellikler göstermemesine rağmen tekil bakış açısıyla yazılmış olması bakımından dikkate değer bir eserdir.

\section{Alaturka Münzevi - Şenol Turan}

Alaturka Münzevi, halen Oltu kaymakamı olarak görev yapan Şenol Turan'ın ilk romanıdır. 1981'de Giresun'un Tirebolu ilçesinde dünyaya gelen Turan, 2005 yilında Galatasaray Üniversitesi İktisadi ve İdari bilimler Fakültesi Uluslararası İlişkiler bölümünden mezun olur. Çardak ve Kabataş ilçelerinde kaymakam vekilliği yaptıktan sonra, Tonya ve Koyulhisar ilçelerinde kaymakamlık ve ardından 2014-2016 yılları arasında Gümüşhane vali yardımcılığ görevini sürdürür. 
Ekim 2011'de Türkiye Cumhuriyeti İçişleri Bakanlığı'nın hazırlamış olduğu Avrupa Birliği Leonardo Da Vinci - Hayat Boyu Öğrenme Projesi kapsamında Paris ve Strasbourg'ta incelemelerde bulunan resmi heyete başkanlık eden yazar, "Demokrat Parti Dönemi Türk Amerikan İlişkileri", "Avrupa Anayasası", "Kriz Yönetimi" ve "Sürdürülebilir Kalkınma" konularına ilişkin akademik düzeyde çalışmalara sahiptir. Oldukça yoğun geçen çalışma hayatına rağmen Turan, Karadeniz Teknik Üniversitesi Sosyal Bilimler Enstitüsü Çalışma Ekonomisi ve Endüstri İlişkileri Bölümünde yüksek lisansını da tamamlar ve 2016 yılında halen sürdürmekte olduğu Erzurum Oltu kaymakamlığına atanır. ("Kaymakam Şenol Turan”, t.y)

Kendisi ile yapılan bir söyleşide yazmanın sırrının okumakta gizli olduğunu aktaran yazar, yazma ve okumanın kendisi için bir tutku olduğunu ifade eder. İlk kitabı Deli Adamlar Ülkesi her ne kadar 2015 yılında yayımlanmış olsa da, Turan'ın kalem denemeleri çok daha eskilere dayanmaktadır. Yazar, öğrencilik yıllarından itibaren amatörce de olsa yazıyla hep iç içedir. Kitap yazmanın bir evveliyatı olduğunu anlatan Turan, söz konusu söyleşide bu durumu: “Okuduğum her şeyden notlar alırım. Belli bir sürede hazırlık dönemi var kitap için. Çalakalem yazdığımız doğru de ̆̆il. Temennimiz Türk edebiyatında güzel bir yerimizin olması. Bunu zaman tayin edecek. Zamanla olacak bir şey. Bunun için de yazmak lazım. Ömrüm vefa ettikçe yazacağım." ("Gümüşhane Vali Yardımcısı", 2016) diyerek dile getirmiştir. Yazar, bir tutku olarak nitelediği ve Deli Adamlar Ülkesi ile başladığı yazarlık serüvenine, 2016 yılında Alaturka Münzevi ve 2018 yılında Kupa Kızını As adlı eserleriyle devam etmiştir.

Yazarın ilk romanı olan Alaturka Münzevi, ismini bilmediğimiz ve romanın sonunda bile asla öğrenemediğimiz merkezi kişinin, yaptığı bir hata sonucu işten atılmasıyla başlar. Eserin merkezi kişisi, çalıştığı gazetede bir haber kaleme alırken "kış turizmi" yazacağ1 yerde yanlışlıkla "kız turizmi" yazar. Onun hayat karşısındaki duruşunun anlaşılmasına da yardımcı olan bu hadiseden sonra hikâye, merkezi kişinin hayata tutunma mücadelesi ile devam eder. On bir bölüme ayrılan eserde "Si Bemol ve Fa Diyez" ile "Galata' da Bir Münzevi" adlı bölümler, romana polisiye bir havanın da karıştığı en ilgi çekici kısımdır. Eserde aksiyonun yükseldiği bu bölümlerin ardından, okurun heyecan ve merak duygusunu kamçılayan belirgin bir hadise gerçekleşmez. Fakat anlatıcının beşeri ve inandırıcı üslubu, anlatının seyrine göre zaman zaman farklılaşan dili, romana ustaca yerleştirilen anı parçaları, rüyalar, mektup ve nutuk örnekleri, Alaturka Münzevi'nin orijinal yönleri olarak göze çarpmaktadır.

\section{Alaturka Münzevi 'de Anlatıcı ve Bakış Açısı}

Daha çok otobiyografik nitelikli eserlerde kullanılan tekil bakış açısı, yazara özü gereği sınırlı ve dar imkânlar sunar. Zira merkezi konumda olan ben anlatıcı her şeyi bilme, sezme ve görme gücüne sahip değildir. $O$, tam anlamıla beşerî özellikler gösterir. Normal bir insanın görebildiklerini görür, sezgisi sınırlıdır ve bilgisi kültür düzeyine göredir. Tekil bakış açısı genellikle ben anlatım yöntemiyle kaleme alınan eserlerde kullanılır. (Tekin, 2016, s. 62)

Edebiyatımızda yeni bir ses olarak nitelenebilecek Şenol Turan, Alaturka Münzevi'de, roman sahasında kendisini kanıtlamış yazarların bile, anlatımda bazı kısıtlılıklara sebep olduğu için pek fazla rağbet etmedikleri ben anlatıcı, diğer bir ifadeyle özne anlatıcı ve tekil bakış açısını tercih etmiştir. Eserde tekil bakış açısı, eserin merkezi kişisi ile bütünleşmiş bir görünüm arz eder. Romanda her şahıs ve her hadise ben anlatıcı tarafından okura aktarılmaktadır. Bu 
nitelik, okura yazarın varlığını daha az hissettirmektedir. Eser, merkezi kişinin işten atıldığını öğrendiğimiz bir pasajla başlar:

“Zaten küçüklüğümden beri kavgalıyız şiirle. Şair olsaydım başka türlü anlatırdım. Lakin böylesi uzun bir hikayeyi tek bir satıra sığdırmak zor! Yekten susuyorum. Diyeceğim, bana bir harföğretenin kırk yıl kölesi olurum. Ama 'z' harfi hariç. 'Kış turizmi' yazacağıma klavye sürçmüş, 'kız turizmi' yazmışım. Kıyamet koptu. Vali aramış, belediye reisi aramış, yetmemiş vekil devreye girmiş. Rıfat denen köpoğlusu geğire geğire, 'Kovuldun!' dediği vakit, az kalsin ikinci cinayetimi işleyecektim." (Turan, 2016, s. 17)

Anlatıcının sıcak bir üslupla verdiği bu haber, ilerleyen sayfalarda merkezi kişinin en yakın arkadaşı Cemil Cengiz tarafından da yorumlanır. Ben anlatıcı, işten kovulma hadisesinde topyekûn suçlu olmadığını düşünmektedir. Fakat Cemil Cengiz hadiseye farklı bir açıdan bakar. Eserin farklı bölümlerinde de tesadüf edilen bu durum, tekil bakış açısındaki sübjektifliği gidermeye katkısı bakımından kayda değer bir uygulamadır:

"Sandalyenin üzerindeki gazeteyi masaya koydum. Kolaylık olsun diye ilgili kısmın altını çizmiştim. Çabucak okudu, 'Hımmm, bak bu çok orijinal' dedi. 'Az bile yapmışlar, ben olsam seni şehirden bile kovardım.'

... 'Böyle hata mı olur?! Resmen hepimizi pezevenk yerine koymuşsun.'

'Bilerek yapmadım'

'Şüphem yok. Ama bunlar dikkat isteyen işler. Hata kabul etmez.'

... 'Ya bırak allasen. Bilmiyormuş gibi. Hepsi omurgasız bunların....Iktidar yalakası artistler.'

'Millet ekmeğinin peşinde oğlum, ne yapsinlar?'”(Turan, 2016, s. 22-23)

Forster (2016) romanda algı sınırlarının ve dolayısıyla bilgi alanlarının genişleme ve daralmasının gerçek hayatı algılayışımıza çok benzediği kanaatindedir. Zira bazı günler diğerlerine göre daha budala olabiliriz. Arada bir, başkalarının zihinlerinden geçenleri okuyabiliriz; fakat bunu her zaman yapamayız. Sonunda bu kesintiler hayatımıza renk ve değişiklik katar. Bazı romancılar da kitaplarındaki kişilere karşı böyle tutarsız davranmışlardır. Fakat Forster bu durumun yazarı eleştirmek için bir sebep olmadığını ifade eder. (s. 121-122) Söz konusu durumun bazı örneklerine Alaturka Münzevi' de tesadüf edilmiştir. Eserde anlatıcı, tekil bakış açısı ile Neslihan adlı roman kişisini iki farklı şekilde okura tanıtır. İlk yapılan tasvirde her şey olumludur. Ben anlatıcı bu karaktere sevgi ile yaklaşır. Aslında onun hakkında çok az şey bildiğini, Neslihan'ın göründüğü gibi olmadığını ise bizim gibi sonradan öğrenir. Söz konusu durum Forster'ın da belirttiği gibi gerçek hayatı algılayışımıza paraleldir. Aşağıda verilen bölüm, ben anlatıcının Neslihan'a dair ilk izlenimlerinden alınmıştır:

"Tanıdığını hiç belli etmedi. Asil kadın doğrusu. Müşteri pozisyonundan bu hale düşmek, gazinodan pavyona düşmek gibi. Neslihan adabımuaşeret biliyor. Belli ki utandırmak istemedi." (Turan, 2016, s. 57)

Anlatıcı bir süre sonra Neslihan'la ilgili yeni şeyler öğrenir ve yanıldığını anlar. Bu durum teknik açıdan bir roman kişisinin aktarılışındaki tutarsızlık olarak yorumlanabilir; fakat okuyucu için hayatta sıkça karşılaşılabilen tabii bir hâldir.

Böylelikle yazar, kahraman anlatıcının beşeri niteliğini belirginleştirirken, kullanılan dilin konuşma diline yaklaştııılması da anlatıcının sınırlı anlatım imkânını genişleterek onu adeta okurla sırdaş kılmıştır: 
"O gece gördü̈̆̈̈m iri kıyım genç Hanımağa'nın Amerika'da okuyan oğluymuş. ...Zengin ve şımarık zengin bebesi işte. Geçen ă̆ustos İstanbul'a gelişinde Hanzade'ye uğramış. ... Gelip gittiği sırada Neslihan'a abayı yakmış. A ̈̆zından girip burnundan çıkmış kızın. Bana abdest suyuyla gelen, hanımefendi pozları takınan, 'Garson dediğin, müşteriyle arasına mesafe koyacak' diye ahkâm kesen bizim haspa da kikirdemiş buna demek ki. Garson Neslihan, Hanımağa'nın Tarabya'daki villasında garsoniyer Neslihan olmuş." (Turan, 2016, s. 83-84)

Ben anlatıcı ile eser yazmanın yazarlar açısından pek de kolay olmadığı söylenebilir. Bu anlatıcı tipinin kaderi beşeri olmak, yani belirli bir bilgi düzeyi, sezme ve görme kabiliyetine sahip olmaktır. Müşahit anlatıcı ile kıyaslandığında anlatımı kısıtlayan bu durumdan kurtulmak için yazarlar birtakım yan uygulamaları devreye sokabilir. Şenol Turan'ın, incelenen eserinde bu tür uygulamaların kullanıldığına şahit oluruz. Bunlardan ilki yazarın, ben anlatıcının kısıtlılığını gidermek için anlatıcıyı daha donanımlı kılma çabasıdır. Eserde, yazarın anlatıcı ve bakış açısı tercihinin doğal bir sonucu olarak ismi verilmeyen merkezi kişinin bilgi ve kültür seviyesi hakkında doğrudan uzun pasajlar halinde malumata ulaşılamaz. Bunun yerine yazar, ben anlatıcıyı okura, onun hadiselere bakış açısı, çevreyi ve eşyayı algılayışı gibi unsurlar üzerinden tanıtır. Bu suretle anlatıcının kültürü ve mizacı hakkında birtakım bilgiler öğreniriz. Sözü edilen uygulamanın ilk örneklerine eserin başlarında tesadüf edilir. İşten atılan merkezi kişi için bu durumun mühim olup olmadığı, onun bu hadiseden sonra kendisi ve çevre hakkında yaptığı bazı yorumlarla ortaya konur. Buradan hareketle okur, onun maddi durumu ve kültür seviyesi hakkında dolaylı şekilde bilgilendirilmiştir:

"Sorularımız mi yabancı bize yoksa cevaplarımı mı? Bana kalırsa sorular. 'Neredesin?' sualine 'Ankara'dayım!' cevabını vermek abes. Doğruyu konuşalım. 'Hakikatte neredesin?','Hüzündeyim şu aralar' ya da 'çıldırmaya çeyrek var!' 'Mutluluğun göğ̈̈s hizasındayım.' ... 'Tam ortasındayım mutsuzluğun!' ...Ben şu an hayret'teyim. İki oda bir salon. Kutu gibi. Hafakanlar basıyor tepeden. Isı yalıtımı iyi yapılmamış koca bir apartman. En üst kattayım ama güneş aldı̆̆ııız yok. Hayret! Hayret işte!"

"Cemil Cengiz'i aradım. ... O gelinceye kadar iki bardak demli çay içtim. Yaklaşık on beş senedir şeker kullanmadığım için çayın tadını daha iyi alıyorum. ... Bu yaşıma dek zaten hayatın tadını alamamıştım. Şekere karşı doğuştan gelen asil bir duruşum var." (Turan, 2016, s. 20-21)

Bunların dışında ben anlatıcı, zaman zaman kendi hislerini okura aktarırken de yukarıda sözü edilen uygulama tekrar devreye sokulur. Yazar, merkezi kişinin maddi durumu kötü olmasına rağmen eğitim seviyesinin yüksek olduğunu ve Neslihan'ı bir türlü aklından çıkaramadığını okura, anlatıcıyı donanımlı kılarak aksettirir:

"Bilim ve teknolojinin miladı olarak kabul gören tekerleğin icadından bu tarafa binlerce yıl geçti. İnsanlık, bugün itibariyle; klonlama, Tanrı parçacığı ve ışınlamayı konuşuyor. ... Ancak bütün bunlara rağmen benim hala bir sevgili yok."

“Teknoloji büyümenin itici gücü haline gelmiş vaziyette. Solow'un 'Büyüme Teorisi'ne göre, büyüme, belli bir aşamaya kadar takviye edici unsurlara gereksinim duymadan kendiliğinden gerçekleşiyor. ...Ne olursa olsun, benim hayatımda Neslihan odakl bir büyüme henüz yok."

“...Matrix filminde işlenen, teknolojinin insanlı̆̆ı esir alacă̆ına dair o bildik felsefe yavaş yavaş hayata geçiyor. İnsanoğlu, hep kendi icat ettiği eşyalar marifetiyle canından oluyor. Araba icat ediyor, trafik kazası; silah icat ediyor, suikast. Benim de ölümüm Neslihan'ın elinden olacak." (Turan, 2016, s. 7374) 
Yazar, romanın bazı bölümlerde, hikaye ile doğrudan alakası olmayan birtakım malumatı da, sözü edilen uygulamayla okura ulaştırır. Bu bölümlerde yazar, değinmek istediği hususları kurguya dâhil ederken oldukça başarılıdır. Zira söz konusu bölümlerin ana metne eklenişi okuru hikayeden koparmayacak nitelik ve uzunluktadır. Bu uygulamanın örneklerinden biri, eserin bir bölümünde merkezi kişinin, Neslihan'ın, kendisi hakkında hayırlı olup olmadığını öğrenmek için istihareye yatması sırasında karşımıza çıkar. Hadise görünüşte Neslihan'la ilgilidir; fakat yazar bu bölümde ilginç bir uygulamaya imza atarak romanla uzaktan yakından ilgisi olmayan pek çok şahsiyet hakkında bilgi verir. İstihare sırasında gördüğü rüyada, merkezi kişinin karşısına meşhur aksakallı dede çıkmıştır. Dede, ona ne amaçla istihare ettiğini bildiğini söyler. Fakat aksakallı dedeye göre, kişi önce kendini bilmelidir. Bu sebeple dede, merkezi kişiden dört tane isim söylemesini ister. Söylenen bu isimler vasıtasıyla o, kendisini tanıacaktır. Bu sırada merkezi kişi isteneni yapar ve dört isim söyler. Bu isimler: Ertem Eğilmez, Yavuz Sultan Selim, Amerikalı fotoğraf sanatçısı Eddie Adams ve Kanuni Sultan Süleyman'dır. Merkezi kişi, isimleri söyledikten sonra aksakallı dede, her bir isim için hatırı sayılır uzunlukta malumat vermeye başlar. Bu bölümlerde, eserin genelinde kullanılan dile göre daha farklı bir dil de devreye girer. Yazar bu yolla tekil bakış açısı ve ben anlatıcı ile kaleme aldığı eserine farklı bir anlatım imkânı kazandırarak bahsetmek istediği şahıslar hakkında, hikâyenin bütünlüğünü bozmadan bilgi vermeyi başarmıştır. Aşağıda verilen bölüm, aksakallı dedenin Kanuni Sultan Süleyman hakkında bilgi verdiği pasajdan alınmıştır:

"Kanuni lakabıyla anılmaya müstahak derecede keyfiyetten uzak bir kanun adamı. İşlediği mücevherler gösteriyor ki, cevahirin kadrini bilen gerçek bir cevher fürüşan. Bütün bunlarm ötesinde, Baki gibi devrinin büyük edebiyatçılarının iltifatlarına mazhar olmuş büyük bir şair. ... O kadar ki, 'Muhibbi' mahlasının çok özel bir yeri vardır divan edebiyatında." (Turan, 2016, s. 79)

Anlatıcının daha donanımlı kılınması, onun kendi başından geçenleri anlatmasının yanı sıra başkalarından dinlediklerini ya da okuduklarını nakletmesi şeklinde de karşımıza çıkabilmektedir. İncelenen eserde Turan, sözü edilen uygulamaya zaman zaman yer verir. Bu yolla hem okura akıp giden hikâyenin arasında farklı bir pencere açılmakta hem de dolaylı olarak okur, merkezi kişinin durumu hakkında bilgilendirilmektedir. Aşağıda verilen bölümler, söz konusu uygulamanın örneklerinden alınmıştır:

"Hikaye malum. Meşhur bir yazar, günün birinde, deniz havası almak için tekne kiralamış. Seyir halinde kaptanla koyu bir sohbete dalmışlar. ... Sohbetin bir yerinde dayanamamış, kaptana, edebiyattan anlayıp anlamadığın sormuş. Kaptan ... 'Hayır, anlamam!' demiş. Beklediği cevabı alan yazar son derece yakışısız ve kibirli bir edayla, 'Desene, ömrünün yarısı ziyan oldu' demiş. Kısa bir süre sonra ani bir fırtına kopmuş... Bu defa kaptan yazara dönmüş, 'Yüzme bilir misin beyim?' diye sormuş. ... 'Hayır bilmem' cevabını alır almaz yapıştırmış lafı: 'Desene, bütün ömrün ziyan oldu.' Kendime dair teşhisi seneler evvel koydum aslında. İnsanlarla iletişim kurmakta zorlandığım için neredeyse bütün ömrüm ziyan oldu... Çekingenlik, kaybetme korkusu... ters giden bir şeyler yüzünden koca ömrüm ziyan oldu." (Turan, 2016, s. 46)

"Yine sıfırdan başlıyorum. Biriktirdiğim ne varsa eskide kaldı. Kimse beni sevmeyecek. ... Bir ölü kadar yalnızım. Bana eşlik edecek kaç kişi var ki? Teselliye ihtiyaç duyduğumda 'öteki ben' var hep! Nihayet o da anladı gerçeği. Pek üstüme varmıyor. Hayallerim un ufak olduğundan, konuşacak bir şey bulamıyoruz. ...Kehle-i İkbal Rüstem Paşa'yı bilirsiniz. Saraya damat olacak. Düşmanları cüzamlı olduğu dedikodusunu çıkardılar. Hekim muayene ederken kıyafetinde bit (kehle) buldu. Bu küçük afacan, Rüstem Paşa'nın cüzamlı olmadığına işaretti. 'Olacak bir kişinin bahtı kavi talihi yar / Kehlesi dahi mahallinde onun işe yarar.'" (Turan, 2016, s. 92,95) 
Romanda ben anlatıcının kısıtlılığını gidermek için kullanılan ikinci bir uygulama da, anlatıcı hakkında doğrudan bilgi veren ya da anlatıcının kendisini tanıtmasına aracı olan bir gözlemci kahramana yer vermektir. Alaturka Münzevi'de bu uygulamanın tam olarak kullanıldığ söylenemese de söz konusu vazifeyi kısmen yerine getiren iki şahıs vardır. Bunlar, merkezi kişinin en yakın arkadaşı olarak tanıtılan Cemil Cengiz ve eserin birkaç bölümünde karşımıza çıkıp daha sonra ortadan kaybolan Ahmet Selim'dir. Aşağıda verilen bölümler sözü edilen uygulamanın Cemil Cengiz karakteri ile ilgili kısmından alınmıştır.

"Köşeyi dönmek üzereyken. 'Kız turizmi' dedi, dayanamadı bastı kahkahayı. 'Ulan sen hiç adam olmayacaksın!' Ben hiç adam olmayacaktım. Beni en iyi tanıyan insanın şaka yollu da olsa hakkımdaki kanaati buydu." (Turan, 2016, s. 24)

“'O kaçamak nerden çıktı?' diye sordu büyük bir merakla. 'Hiç yapmayacağın işler. Bugüne kadar harama uçkur çözmüş adam değilsin.' ...'Ölümden dönmüşsün resmen. Oğlum senin normal bir işin olmayacak mı?'" (Turan, 2016, s. 115-116)

Ahmet Selim, merkezi kişinin tesadüfen izlediği bir sema töreni sonrası hayatına giren ve onu çok etkileyen bir roman kişisidir. Aşağıdaki bölümler, onun Ahmet Selim'le olan diyaloglarından alınmıştır:

“Konuştuğumuz gibi saat tam sekizde Galatasaray Lisesi'nin önünde buluştuk. ...'Açlığın var mı?' diye sordu. Benim gibi birinin başka nesi olur. 'Evet' anlamında başımı salladım. ...Sonra nasıl olduysa sessizliği bozdu. 'Az konuşuyorsun' dedi. ... Ne cevap vereceğimi bilemedim. 'Íbrahim Hakkı Hazretleri bu konuda güzel bir ölçü koymuş' dedi. 'Az ye, az uyu, az konuş' demiş. Tebessüm etti. Ne cevap vereyim şimdi? 'Güzel söylemiş' dedim. Benim de hayatıma bire bir tatbik ettiğim bir formüldür. Maddi olanaklardan yoksun olduğum için az yerim; yalnız olduğum için az konuşurum. Fazla uyuduğum söylenemez." (Turan, 2016, s. 131-132)

Yazar, ben anlatıcının kendisini tanıtma konusundaki kısıtlılığını ortadan kaldırmak için gözlemci kahramanı kullanmaktan ziyade çeşitli vesilelerle merkezi kişinin kendi kendisini tanıtmasına zemin hazırlamıştır. Eserde merkezi kişi, yaşanan çeşitli hadiseler sonrası kendisi ile ilgili bilgiler vermektedir. Yazar, söz konusu bölümleri kalemini ustaca kullanarak hikâyenin akışını bozmadan ana metine bağlamıştır. Aşağıda verilen bölüm, merkezi kişinin işten atılması sebebiyle kirayı geciktirdiği ve bu sebeple para canlısı ev sahibinin, kendisine kötü davrandığı sahneden alınmıştır:

“Kira gecikti diye ağız eğmesi ....ayıp. Benim kabahatim mi? İșten kovdu haydutlar. ...Amerikalı psikolog Abraham Maslow, insan ihtiyaçlarını piramit şeklinde tasarladığı bir düzenek marifetiyle öncelemeye çalışmış. ... Ben henüz birinci basamaktayım.. Daha hala fizyolojik gereksinimlerle boğuşuyorum. Otuz beş sene önce başladığım yerdeyim. Besin, su ve boşaltım." (Turan, 2016, s. 100)

Romanda merkezi kişi, zaman zaman arkadaşlarından bahsederken ya da basit bir yemek sahnesinde bile bir vesile ile yine kendinden söz edebilmektedir:

"İki değgerli insanın, iki beyzadenin ortak tanıdığı olmak gurur verici. Şimdi, tam şu anda, gökten zembille bir melek inse, ve, 'Bu hayatta en büyük başarm nedir?' diye sorsa cevabım hazır:' Cemil Cengiz ve Ahmet Selim'in ortak arkadaşı olmak.' ...Bu mutluluk bana yeter. Fazla bir beklentim yok hayattan. Küçük şeylerle mutlu olabilen biriyim ben."

“Servisi yapan Figen'e, 'Lütfen benimki az olsun' dedim. Gözlerine bakamadım. Korkuyorum. Saatleri Ayarlama Enstitüsü'ndeki Hayri İrdal gibiyim. Nedensiz bir çekingenlik var üzerimde. ...Patlıcan musakkayı da az isteyince pişman oldum. Kadınlar yemek konusunda titizdir. Beğenmediğimi 
düşünecek şimdi. ... Oysa benim midem küçük. Küçüklü̈̆̈̈mden beri yemekle aram iyi değildir. Pek bulamadığım için yemek seçmem hiç. Sadece az yerim. Az bulduğum için az yerim. O sebepten midem küçük." (Turan, 2016, s. 160,169)

Bu uygulama eserin bazı bölümlerinde bir adım öteye götürülmüş ve ben anlatıcı doğrudan okurla diyaloğa girerek kendisini tanıtmıştır:

“Görüyorum ki pek çoğunuzun kafasında şekillenen hakkımdaki iflah olmaz şıpsevdi yargısı üzerine birkaç şey söylemem gerekiyor. Ben öyle birisi değilim. Hiçbir zaman da olmadım. Mehmet Nazif'in kızı ya da Neslihan, hatta hayatıma şöyle ya da böyle, kıyısından ya da köşesinden bir şekilde girmiş ve girecek olan bütün kadınlar, esasında aynı kişi. İsimlerifarklı olabilir, yaşları aynı olmayabilir. Esasında ben hep aynı kadına âşık oluyorum." (Turan, 2016, s. 37)

Eserinde ben anlatıcıyı tercih eden bir yazarın anlatım imkânını genişletmek adına yapabileceği bir diğer uygulama da mektup ve anı gibi türlerden yararlanmaktır. Romana yerleştirilen anı parçaları ve mektuplarla anlatıcının hayatı ve kültürel konumu hakkında okura bilgi vermek mümkündür. Alaturka Münzevi'de sözü edilen bu üçüncü uygulamayı da kullanan yazar, farklı bir yolla mektup türünü devreye sokmuş; fakat anılara çok fazla yer vermemiştir. Aşağıdaki pasaj, anıların kullanımı ile ilgili az sayıdaki örnekten biridir:

"Benim bastığım yerde ot bitmez. Vaktiyle ihtiyar bir amca evine davet ettiydi. Beraber dama çıtık. Baş açı!! Yürüyoruz. Neden sonra fark ettim. 'Beni buraya niye çıkardın ihtiyar?' diye sordum. 'Af buyur' dedi. 'Şu çimler yüzünden dam akıtıyor, methini çok duyduk, bastığın yerde ot bitmezmiş.'” (Turan, 2016, s. 94)

Mektup türünün romanda kullanımı genellikle, mektupların karşılıklı yazılması şeklinde karşımıza çıkar. Fakat Alaturka Münzevi' de yazar, mektubu ben anlatıcının iç diyalogları gibi kullanır. Sözü edilen uygulamanın en güzel örneklerinden biri merkezi kişinin, ütopik sevdası Neslihan hakkında öğrendiği gerçeklerin ardından, asla okunamayacağını bildiği halde ona yazdığı mektuptur. Aşağıdaki bölümler söz konusu mektuptan alınmıştır:

“Bir mektup yazdım sana. Oku ya da okuma! Sonra bu mesele sonsuza kadar kapanacak.

Sevgili Sen, Hiç kızmıyorum sana. Zerre kabahatin yok... Bütün kabahat benim. Bir erkeğe yedi defa gülümsemenin bedeli bu kadar ağır olmamalı. ... Küçücük bir odada büyük hayaller kurdum senin için. Hepi topu otuz metrekare. Karyolam tam köşede. Geçen yaz Osman Bey'den aldığım turkuaz mavisi nevresimi kullanıyorum. Bana benziyor. İdiasız bir şey. ...Onun dışında, yazı yazmak için kullandiğım orta boy bir masa ile kitaplarımı koyduğum ikinci el bir kitaplığım var. Hepsi daha önce bir başkası tarafından kullanılmış. Tıpkı senin gibi." (Turan, 2016, s. 86-88)

Anı ve mektup türünün dışında Turan, eserinde okurun merkezi kişi hakkında bilgi sahibi olmasını kolaylaştıran ve romanda ben anlatıcının sınırlı görüşünü genişleten iki malzemeyi daha işe koşar. Söz konusu malzemeler merkezi kişinin gördüğü absürt rüyalar ve topluluklar karşısında yaptığı hayali konuşmalardır.

Merkezi kişinin, karşılıksız aşkı Neslihan'ın, zengin bir gençle olan münasebetini öğrenmesi neticesinde içinde bulunduğu melankolik ruh hali ile yaptığı hayali konuşma, okur için hem hikâyenin statik akışından çıkmayı sağlayan hem de merkezi kişiyi daha yakından tanımaya imkan veren güzel bir örnektir:

“İstek ve arzularımı toplumun üstüne bir deli gömleği gibi giydirmek istiyorum. Âşık olduğum bütün kadınlar gelsinler. ...Büyük bir meydanda toplanalım. ...Bütün patronlar gelsin. Tek ayaküstünde 
görmek istiyorum onları. ... Bugün matem günüdür. Günün anlam ve önemine uygun kısa bir konuşma sadece. 'Dostlar, Romalılar, Kardeşlerim! Daha dün ben de sizler gibi mümtaz bir ilim irfan ehliydim. Şu halimi görüyorsunuz. Üzerimde hepinizin emeği var. İnkâr edemem. ...Gövdemin üzerinde şekilsiz bir şekilde durmakta olan kafamın varlığına şahit olmaya başlamam üniversite yıllarına tekabül ediyor. ...Ortaokul ve lisede altı yılda öğrendiklerimi unutmak için bir altı yıla daha ihtiyactm vardı. Yirmi birinci yüzyılda, on sekizinci yüzyıl zihniyetiyle öğrenci yetiştiren milli eğitim müfredatının kurbanı olmuştum.' ...Alkış itemediğim halde alkışladılar. Delirtmek için her şeyi yaptım. Olmadı. Yine delirttiler beni. ...Programın finalinde tarafıma 'Yaşayan En Değerli kırık Kalp Ödülü' takdim edildi. 'Siz olmasaydınız bu ödülü alamazdım' dedim. 'Senin hakkındl, sonuna kadar hak ettin' dediler. 'Sizin sayenizde' diye ekledim." (Turan, 2016, s. 92-95)

Eserde rüya örneklerinden biri olan ve daha evvel bahsedilen istihare rüyasının dişında merkezi kişinin işten kovulma hadisesinden sonra gördüğü bir rüya daha vardır. Eserin başlarında karşımıza çıkan bu rüya sayesinde yazar, okuru merkezi kişinin kültür seviyesi hakkında doyurucu bir bilgiye ulaştırır. Zira görülen rüyada hayli renkli şahsiyetler vardır. $\mathrm{Bu}$ rüyada, ben anlatıcı kendisini kalabalık bir mecliste bulur. Meclisin ahalisi Demokles, Thomas Hobbes, Macchivelli, Voltaire, Henry David Thoreau, Albert Einstein, Goethe, Napolyon, Sigmund Freud, Aristo, Shakespeare, Salvador Dali, Newton ve Münir Özkul'dan oluşmaktadır. Bu isimler Münir Özkul, nam-1 diğer Kel Mahmut eşliğinde "Hababam Sınıfı"na benzeyen bir mekânda toplanmıştır. Öğretim yılının başlarındadırlar ve sınıf mümessili seçilecektir. Bu sahne içerisinde merkezi kişi, hemen her şahsiyetle diyaloğa girer ve aralarında bu isimler hakkındaki malumatını gözler önüne seren konuşmalar gerçekleşir. Yazar bu yolla hem tekil bakış açısından kaynaklanan dar görüşünü genişletmiş hem de dolaylı yoldan sözü edilen şahsiyetlerden bahsetme fırsatını yakalamıştır. Aşağıda verilen pasajlar, söz konusu rüyadan alınmıştır:

"Biz Aristo ile laflarken Einstein aldı sahneyi. Dili dışarda, kara tahtaya tebeşirler epey bir formül yazdı.

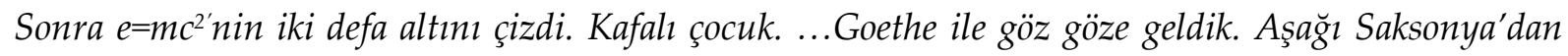
hemşeri bunlar. Belki o anlamıştır umuduyla çaktırmadan ona sordum. 'Boş veer, şimdi Newton düşünsün!' dedi. Newton'a baktım, hakikaten kara kara düşünüyor. ...Henry David Thoreau ile Thomas Hobbes birbirine girmişti. Sonradan duyduğumuza göre Henry itaatsizlik etmiş. Anlaşmayı hiçe saymış. ... Machievelli laf attı arka sıralardan. 'İki gözüm, amaç başkan olmaksa şayet...Amaca giden her yol meşrudur!' Ben, 'Neler oluyor...Allahım aklıma mukayyet ol!' diye düşünürken elinde kuru kafayla Shakespeare atıldı sahneye: 'Başkan olmak ya da olmamak, işte bütün mesele bu!'”' (Turan, 2016, s. 25-27)

Ben anlatıcının kullanımında anlatımdaki sınırlılığı gidermek üzere yapılan bu uygulamaların dışında yazar Alaturka Münzevi' de, Nurullah Çetin'in (2015) "iç söyleşme" olarak tanımladığ1 bir tekniği de devreye sokar. İç söyleşme, roman kişisinin gerçekte karşısında kimse olmadığı halde birileri varmış gibi kabul ederek onlarla yaptığ 1 hayali konuşmalardır. (s. 181) İç söyleşme, iç monolog, iç diyalog ve bilinç akışı gibi tekniklere kıyasla, hadiseleri zihinde canlandırmaya daha müsait bir zemin hazırlar. Bu bakımdan iç söyleşmenin kullanımı, incelenen eserde tercih edilen anlatıcı ve bakış açısı düşünüldügünde, anlatıya hareketlilik getiren yerinde bir uygulama olarak değerlendirilebilir. Aşağıdaki bölüm, merkezi kişinin çok sevmesine rağmen bir türlü açılamadığı Neslihan isimli kızla yaptığı hayali söyleşmeden alınmıştır. Burada merkezi kişi, genç kıza yaklaşmak için üç farklı yolu zihninde canlandırır. Bu bakımdan sözü edilen bölümde okur, adeta bir film sahnesinin üç ayrı çekimine şahit 
olmaktadır. Yazar bu suretle ben anlatıcının zihninden geçenleri iç diyalogla vermek yerine, yaşanmamış olmasına rağmen sahneleme tekniği ile verme imkânını elde etmiştir:

“Neslihan... İşte orada. ...Takip etsem mi acaba? Hayır, hayır burada değil. Akşam evine giderken. Yakalanırsam bir çuval incir berbat olur. Şöyle bir mizansen:

'Aaa, sen ne arryorsun burada?'

'Şeyy, eve gidiyorum.'

'Nerde oturuyorsun?'

'Samatya'da'

'İyi ama bu Saruyer otobüsü'

'Haklısin Neslihan. Daha fazla saklamanin bir anlamı yok. Seni takip ediyorum.'

'Anlamadım?'

'Ben sana sırılsıklam âşı̆̆ım Neslihan!'

'?!!!'

'Varliğına eşdeğer bir mutluluk, yokluğuna eş değer bir hüzün yok Neslihan.'

... Biraz fazla Türk filmi oldu sanki. Beyaz perde, seyirciyle arasındaki siyah perdeyi kaldıracak daha doğal bir dil kullanmalt. Şöyle olabilir belki:

'Merhaba Neslihan.'

'Merhaba.'

'Sen şimdi burada ne aradığımı merak ediyorsun. Boşuna yorma kendini. Seni takip ediyorum. Takılalım mı biraz?'

'Anlamadım?'

'Birlikte vakit geçirelim diyorum. Bilirsin işte. Isınma turları.'

Bu hiç olmadı. Baştan sona zıpır. Muzır neşriyat. Neslihan öyle bir kız değil. Ben öyle bir insan hiç değilim. Galiba yine şöyle bir şey olacak:

'Merhaba. Tanışabilir miyiz?'

'İyi ama biz tanışıyoruz zaten.'

Ve esas oğlan, 'Haklısın' der, arkasını döner ve kadrajdan çıkar." (Turan, 2016, s. 63-64)

Yazar eserinde iç söyleşme uygulamasını bir adım öteye daha taşıyarak merkezi kişinin zihninde, iki farklı şahsın konuşmasını da okurla paylaşır. Bu uygulamada merkezi kişi, zihninde söyleşen şahısları uzaktan seyreder bir hava içindedir. Bu durum bir nevi merkezi kişinin içindeki iki ayrı hissin vücut bulmasıdır. Çetin (2015) bu uygulamayı iç konuşmanın bir başka türü olarak niteler. Burada kişinin 1.beni yani sağduyusu ile 2.beni yani yanılabilen, şartlara göre değişebilen kişiliği karşılıklı konuşmaktadır. ( s. 180) Aşağıdaki pasaj, söz konusu uygulamadan alınmıştır:

"Notunu aldı ve gitti. Salına salına. Ardında bir enkaz bırakarak. Beni hala, bütün derdi akşam yemeği olan sıradan bir müşteri sanıyor. ...Akabinde fajitas gelinceye değin kafamın içinde türlü hayaller kuruyorum. Yapboz tahtası gibi. Ha bire bozuyorum. Beynimi sürekli kemiren iki ses var. Arçil ve Şota 
kardeşler. Biri devamlı iteliyor, 'Haydi, tam zamanı!' diye. Diğeri öteliyor, 'Sakın ha, sırası mı şimdi?' Sonra başliyor bir curcuna. 'Sana kalsa o vakit hiç gelmeyecek.' 'Öyle deme, üzülsün istemiyorum. Şimdilik savunmada kalalım.' 'Açık oynamahyız. En iyi savunma hücumdur' 'Savunmada az kişiyle yakalanırsak biteriz. Açık vermeyelim. Duvara toslamak mı istiyorsun?' ... 'Ah bir frikik verse...' ' Hössstt! Gevşeme hemen.'" (Turan, 2016, s. 44-45)

\section{Sonuç}

Oltu kaymakamı Şenol Turan tarafında kaleme alınan Alaturka Münzevi, edebiyat dünyasında kendisini kanıtlamış yazarların bile tabiatındaki kısıtlılık dolaysıyla fazla itibar etmedikleri ben anlatıcı ve tekil bakış açısı ile yazılmıştır. Sözü edilen anlatıcı ve bakış açısı, roman sahasında daha fazla kullanılan müşahit anlatıcı ve tanrısal bakış açısına kıyasla, yazara daha dar bir anlatım imkanı sunar. Müşahit anlatıcının her şeyi bilen, gören ve sezebilen yapısına karşılık ben anlatıcının evreni yalnızca kendisi ile sınırlıdır. Tanrısal bakış açısı ile taçlandırılan bir müşahit anlatıcı, olmuş ve hatta olacaklara kadar uzanan bilgisi ile okura çok daha sınırsız bir dünya inşa edebilir. Bu bakımdan tekil bakış açısı ve ben anlatıcıyı tercih eden bir yazarın, anlatıcısını ne kadar bilgili kılarsa kılsın iflah olmaz bir sorunu daha vardır. Bu sorun, ben anlatıcının kendisini tanıtmadaki yetersizliğidir. Sözü edilen bu durumu aşabilmek için yazarın bazı yan uygulamaları devreye sokması gerekir. Alaturka Münzevi'de Şenol Turan, merkezi kişinin kendisini okura tanıtabilmesi için, anlatıcıyı daha bilgili ve donanımlı kılmak, gözlemci kahramana yer vermek, anı ve mektup gibi türlerden yararlanmak, merkezi kişinin doğrudan kendisini tanıtmasına zemin hazırlamak, iç söyleşme ve iç diyaloglara yer vermek gibi birçok imkânı kullanmıştır.

İsmi verilmeyen ben anlatıcı, üniversiteyi son sınıfta terk eden, bilgi ve kültür seviyesi hayli yüksek; fakat maddi durumu kötü bir roman kişisi olarak inşa edilmiştir. Yazar bu yolla, anlatıcısını pek çok farklı bilgi alanı için kendisinin sözcüsü konumuna getirirken göze batmamayı başarır. Eserde zaman zaman yer verilen karşılıksız mektuplar, merkezi kişinin his ve fikirlerini okura farklı bir mecradan ulaştırmış böylelikle yazar, sürekli iç monolog ya da iç diyalog kullanarak tekrara düşmek yerine, okura daha orijinal ve dinamik bir metin kazandırmıştır. Bunlardan başka yazarın, merkezi kişiye ait bazı rüyalara yer vermesi, bunları metne yerleştirme biçimi ve rüyaların içeriği, hem merkezi kişinin tanıtılmasına hizmet etmiş hem yazarın değinmek istediği şahıs ve konuları tabii bir biçimde okurla paylaşmasını sağlamış hem de daha sıcak bir üslupla anlatıcı ve okur arasında samimi bir bağ kurulmasına zemin hazırlamıştır. Genellikle otobiyografik nitelikle metinlerde kullanılan ben anlatıcı ve tekil bakış açısı -eseri bu niteliği taşımamasına rağmen -Turan'ın kaleminde okuru içine çekmeyi başaran etkili bir anlatım imkânı haline gelmiştir.

\section{Kaynakça}

Aktaş, Ş. (2003). Roman sanatı ve roman incelemesine giriş. Ankara: Akçă̆ Yayınları.

Çetin, N. (2015). Roman çözümleme yöntemi. Ankara: Akçă̆ Yayınları.

Forster, E. M. (2016). Roman sanatı. Ü. Aytür (Çev.). İstanbul: Milenyum Yayınları. 
Gümüşhane vali yardımcısı Şenol Turan'ın kitap tutkusu. (2016, 22 Kasım). Erişim adresi https://www.milliyet.com.tr/yerel-haberler/gumushane/gumushane-vali-yardimcisisenol-turanin-kitap-tutkusu-11661971 ET. 25.08.2020.

Moran, B. (1983). Türk romanına eleştirel bir bakış 1, İstanbul: İletişim Yayınları.

Oltu kaymakamı Şenol Turan özgeçmiş. (t.y) Erişim adresi http://www.oltu.gov.tr/kaymakam-senol-turan_E.T. 19.08.2020

Tekin, M. (2016). Roman sanatı I, İstanbul: Ötüken Neşriyat.

Turan, Ş. (2016). Alaturka münzevi, İstanbul: Doğan Kitap. 